\title{
AUDITING AND AUDIT FIRMS IN GERMANY BEFORE 1931
}

\begin{abstract}
Considerable differences exist between Germany and AngloAmerican countries in the development of the statutory audit, the emergence of professional associations of auditors, and the legal and organizational forms of audit firms. This paper examines historical developments in Germany from the late 19th century, to the formal regulation of auditing and the audit profession in 1931. Its main objective is to provide a better understanding of the comparatively slow development of the audit in Germany and reveal attitudes towards the audit and the forms of audit firms. A secondary objective is to examine the use of agency theory frameworks for this type of historical research. The study draws on primary and secondary sources, both of which have been underutilized by previous authors. The paper finds that many of the unique features of the development of auditing in Germany and the solutions adopted there can be traced to historical differences concerning the objectives of the audit, the structure of the audit market and the foundations of the audit profession. It further adds to the critique of agency theory assumptions in historical contexts.
\end{abstract}

\section{INTRODUCTION}

The histories of the statutory audit and the auditing profession in Germany contrast significantly with their development in Anglo-American contexts. In the UK, for example, the statutory corporate audit was first introduced in 1844, abandoned (for most sectors) in 1856 and reintroduced by the Companies Act, 1900. During the 19th century the accounting profession emerged as a number of separate associations - the earliest

Acknowledgments: The author is grateful for help and advice from Reiner Quick, Stephen Walker, Falconer Mitchell, Aage Johnsen, Hugh Brian Markus, and the participants of the 2001 annual conferences of the European Accounting Association and the British Accounting Association Special Interest Group on International Accounting and Finance. Thanks are also due for comments received at the first European Auditing Research Network Symposium, October 2001. Helpful suggestions from two anonymous referees are also gratefully acknowledged. 
being the organizations formed in Edinburgh and Glasgow in 1853. In Germany, however, both the statutory audit and professional associations were to appear much later. While market demand for the audit developed slowly during the late 19th to early 20th centuries, and audit firms and professional associations emerged to meet this demand, the annual audit of financial statements remained voluntary in Germany until 1931. This was despite active lobbying for state regulation by the heterogeneous profession. A further contrast between the British and German audit markets is the different legal and organizational forms that have been preferred for audit firms. German audit firms, especially larger ones, have traditionally favored a corporate form of organization. Independent practices of sole proprietors or loose forms of partnerships (which mainly served the sharing of resources and were not legal entities) were alternative forms. Partnerships in the British sense are a very recent development in Germany. In the UK on the other hand sole proprietorship and partnership were the only legal forms available to audit firms until 1991.

The objective of the present paper is to shed light on the comparatively slow development of the statutory audit in Germany, examine the different attitudes to the legal and organizational forms of audit firms, and to analyze the development of German auditing and audit firms prior to their statutory regulation in 1931. Specifically, the paper aims to examine the validity of suggestions that the German audit profession was created by the state, unlike that in the UK, which is claimed to have been created by market forces. In examining the origin of the German audit profession, the paper traces the history of two very different groups, whose disputes over market share and audit regulation may have contributed to the need for government interference. Further, the paper focuses on the background to the preference for the corporate form of audit firms in Germany and examines contemporary arguments for and against this form. This issue was significant because it divided the two branches of the profession in Germany. The paper does not attempt to take an overtly comparative approach between Germany and the UK. While professionalization issues have been explored for the latter [see for example, Willmott, 1986; Walker, 1995; Matthews et al., 1998], much less is written on the German case [but see Meisel, 1992; Markus, 1997; Gietzmann and Quick, 1998]. The present contribution seeks to extend understandings of the peculiar development of the institutions of auditing in Germany. 
While the author is aware of alternative approaches to historical scholarship the paper is loosely based on an agency theory framework. This approach is adopted for a number of interrelated reasons. Firstly, agency theory claims to explain the development of the independent external audit in the UK and US. Secondly, Watts and Zimmerman [1983] use historical data, namely an examination of the development of the independent audit, as evidence to support their theory. Further, an agency theory approach has been used in historical research by, for example, Gray and Calvasina [1995, p. 35] in the expectation that it would "enhance our understanding of agency relationships and foster[s] greater recognition of the limitations and hazards of historical research using an agency literature framework" [see also Mills, 1993]. Thus a subsidiary objective of this paper is to consider the limitations of Watts and Zimmerman's assumptions, specifically in a historical, nonAnglo-American setting and to extend the critique of agency theory.

Further, and of particular relevance to the focus of this paper, there exists a considerable body of literature on agency theory which confidently declares that the partnership form of business organization is most suited to professional audit firms. However, a rudimentary knowledge of the profession outside the US and UK suggests that the corporate form has been popular among audit firms in other countries [see, for example, the avant project - the unpublished working draft - to the Eighth European Union Company Law Directive, Working Party on Auditing, 1972]. These contrasts raise questions about the agency theory framework and invite critical scrutiny.

A combination of primary and secondary sources on the history of German auditing and the audit profession were used for this study. Secondary sources comprised literature in English and German. Primary sources used were German legislation, and commentaries and contemporary views expressed in academic or professional literature. Business journals were established early in Germany. Their content reflects the emphasis on academic education in business subjects, the early creation of business schools, and the fact that it was common for practitioners as well as academics to publish in these journals. As well as journal articles, contemporary academic theses and textbooks provided material for the current study. Many of the latter reveal somewhat amateurish scholarship and are often unashamedly biased. A further rich source was provided by publications in years immediately following the period under 
investigation, where authors contrasted recent changes with historical experiences.

The remainder of the paper is structured as follows. The next section introduces the agency theory framework. Then follows an overview of the history of the German profession from its beginnings until 1931, when the annual external audit became a legal requirement for large corporations and the profession was regulated by statute. This section focuses in particular on the conflicts between the two branches of the audit profession during the late 19 th and early 20 th centuries. These conflicts related to regulation, organization and market share. The penultimate section discusses the main findings with reference to the agency theory framework. The final section presents a brief summary and conclusions.

\section{THE AGENCY THEORY FRAMEWORK}

Agency problems and costs arise from the separation of ownership and control in modern companies. This separation gives rise to agency relationships between the owners and those who manage the company on their behalf. Jensen and Meckling [1976, p. 308] define an agency relationship "as a contract under which one or more persons (the principal(s)) engage another person (the agent) to perform some service on their behalf which involves delegating some decision making authority to the agent". Problems arising from this relationship relate to the fact that the agent, as utility maximizer, may not act in the interest of the principal. ${ }^{1}$ Agency and related theories claim that agency problems between shareholders and management led to the development of the independent external audit (as a monitoring and bonding mechanism) and that the legal form of partnership avoids or minimizes agency problems within the audit firm. Financial reporting is the means by which management (the agents) discharge their accountability to the shareholders (the principals). Watts and Zimmerman [1986] claim that: "[t]he demand for accounting arises from its use in contracts that

\footnotetext{
${ }^{1}$ The principal can attempt to limit this effect by creating incentives for the agent to act in the principal's interest, and by monitoring the agent's behaviour, or arranging for this to be done on his behalf (giving rise to monitoring costs). The agent may also expend resources to reassure the principal that he will not act against his interest (bonding costs). In spite of these safeguards, however, the agent's decisions cannot be guaranteed to maximise the principal's welfare, which gives rise to an additional cost to the principal (residual loss) [Jensen and Meckling, 1976].
} 
reduce the firm's agency costs. However, those contracts are of little use in reducing agency costs unless their provisions are monitored and enforced. Auditing is one of the ways in which the contracts are monitored" [Watts and Zimmerman, 1986, p. 312].

The assumption that auditing is one of the ways of reducing agency costs led Watts and Zimmerman to examine the suggestion that "independent audits are expected in the earliest firms where the manager did not supply all the capital" [1983, p. 613]. They found that monitoring and auditing existed early in the history of business organizations, and eventually developed into the audit as required in British legislation during the 19th century. They also stated that early audits were carried out by insiders (directors/shareholders). The independent audit, carried out by professionals, did not develop until the mid 19th century in the UK and the early 20th century in the US, and predated the legal requirement. Watts and Zimmerman [1983, p. 614] concluded that "the use of professional auditors was due to changes in the market for auditing". These changes resulted from increased numbers of companies, increased company size, and the reduced cost of ensuring auditor competence and independence. The latter was the result of the formation of professional associations from the middle of the 19th century [Watts and Zimmerman, 1983]. Watts and Zimmerman dismiss the alternative suggestion that independent audits in the UK and US were created by government regulation. Contracting theory claims to explain not only the existence of audits but also the significance attributed to audit firm reputation and the existence of professional associations, the organizational form chosen and the audit firms' size and industry specialization. These three claims are explored below.

Reputation and Professional Associations: According to Watts and Zimmerman [1986, Chapter 13], audits only have value if they lead to a reduction of agency costs. This will only be the case if the market is convinced of the auditor's competence (to discover a breach of contract) and independence from management (i.e. the likelihood that he/she will report a breach of contract). The market will only be convinced of the auditor's independence if there are sufficient incentives for the auditor to be independent. Such incentives include reputation (and the ability to charge higher fees) and the existence of professional societies (since a system of accreditation can support the auditor's reputation for competence and independence, which is signaled by a 
"brand name" such as "chartered accountant") [Watts and Zimmerman, 1986]. Further, since in professional partnerships (including audit firms) there are usually few assets available to serve as a bond against the risks of adverse selection or moral hazard [Milgrom and Roberts, 1992, p. 523], reputation and membership of a professional association can serve as the auditor's collateral (since loss of reputation and/or loss of membership in a professional body would lead to a loss of fee income) [Watts and Zimmerman, 1986]. Further, the fact that partners are residual profit owners increases their motivation to build a strong reputation.

Organizational Form: An advantage of the partnership is that unlimited liability provides, in the form of the partners' personal assets, a larger bond than would be available in an incorporated audit firm with limited liability [Watts and Zimmerman, 1986, p. 317; Milgrom and Roberts, 1992, p. 523]. This is especially because audit firms tend to have few assets which could serve as a bond. Thus: ". . . if auditors incorporate with limited liability, they reduce the amount of assets available as a bond on their actions. The market will appropriately reduce its assessed probability of their independence. Ceteris paribus, unlimited partnerships provide a greater bond on the auditors' independence" [Watts and Zimmerman, 1986, p. 317]. However, a disadvantage of this is that in a partnership with unlimited liability, risk is not divisible or transferable. ${ }^{2}$ This will lead investors to spend additional resources on monitoring, or not invest at all [Milgrom and Roberts, 1992, p. 522]. Further: "[t]his factor constrains partnerships from expanding the number of partners and reducing the amount invested by each to permit better diversification. Similarly it makes it expensive for partnerships to expand into different lines of business or into new geographical markets because such moves increase the cost of monitoring" [ibid.]. However, the need for outside capital is generally limited due to low capital requirements - the most important asset of a partnership is human capital. Further, in the partnership form individual partners are jointly and severally liable. Liability for the other partners' work provides a strong incentive for mutual monitoring [Milgrom and Roberts, 1992, p. 523]. Mutual monitoring by partners who are liable for each other's actions, provides further

\footnotetext{
${ }^{2}$ It may be transferable through insurance. However, it has been argued by the UK profession that it is difficult to obtain sufficient cover at a reasonable cost.
} 
incentives for increasing competence and independence and reduces the risk of an individual auditor bending to management influence [Watts and Zimmerman, 1986]. ${ }^{3}$

Greenwood, Hinings and Brown [1990] argue, with respect to large professional partnerships, that these contrast with other large organizations in that ownership and governance structures are different, and because work is carried out almost exclusively by "self-contained" professionals. Greenwood et al use the accountancy industry as an example and find that: "In summary the task of accounting firms is professional in that it requires the application of professional knowledge to complex situations, and the work itself is individualized, geographically dispersed, and geographically differentiated" [Greenwood et al, 1990, p. 733]. As a result, authority and decision making structures in partnerships differ from those in corporations.

Size: Fama and Jensen [1983a] consider size to be an important factor in the context of the separation of ownership and control (or risk-bearing and decision making). In professional partnerships most decisions are made locally: "At this level, however, decision management and decision control are not separate. To control the resulting agency problems, the residual claims in professional partnerships, large and small, are restricted to the professional agents who have the major decision-making roles" [Fama and Jensen, 1983a, p. 316]. In small partnerships, as with sole traders and close corporations, decision-makers are usually the residual risk bearers. However, in large professional partnerships, residual claims are diffused; residual risk-bearing and decision management may be separate. This requires the existence of strong mutual monitoring systems common in other complex organizations. Yet, because all the residual claimants are experts in the professional partnership's activities, there is little demand for monitoring by outside experts [Fama and Jensen, 1983a]. Further, monitoring by outsiders (non-experts) is difficult [Milgrom and Roberts, 1992, p. 523]. Finally, decision control systems are similar between all such types of organization open corporations, large professional partnerships, financial mutuals and nonprofits etc. [Fama and Jensen, 1983a, but see

\footnotetext{
${ }^{3}$ For example, Watts and Zimmerman [1986, pp. 316-317] argue: "It is interesting that before the development of the professional audit firm the audit was conducted by a committee of shareholders. The committee form makes it more difficult for the manager to bribe the auditor, particularly with mutual monitoring by the committee members".
} 
Greenwood et al., 1990, above]. Firm size may also be related to independence and competence, since larger firms provide economies of scale for the development of brand-names, offer larger bonds and better opportunities for mutual monitoring [Watts and Zimmerman, 1986].

The validity of many of these explanations for the development of the external corporate audit and the organization of audit firms could, and to some extent have been, subject to criticism in the UK context. While it is not within the scope of this paper to provide a critique of agency theory in Anglo-American settings, it should be noted that critics of positive theory, of which agency theory forms a part, challenge its philosophical foundations [Tinker, Merino and Neimark, 1982; Chua, 1986] and the neo-classical assumptions which underpin agency theory [Chua, 1986; Hunt and Hogler, 1990]. The theory's methodology is also challenged, in particular, the fact that few attempts have been made to test the theory through conventional scientific approaches of falsification [Christenson, 1983]. Further, Hunt and Hogler [1990] question Jensen and Meckling's [1976, p. 310] assumption that the firm is a "legal fiction which merely serves as a nexus for contracting relationships" and consider it a weakness that agency theory appears unable "to address issues that do not revolve around identifiable, marketbased contracting relationships, or to analyze imbalances of power inherent in the social context of an organization" [Hunt and Hogler, 1990, p. 443; see also Chua, 1986]. They also criticize the theory for its ideological foundation and the assumption that accountants behave as objective, unbiased experts, with no concern for policy and social consequences [see also Tinker, et al., 1982; Chua, 1986; Broadbent, Dietrich, and Laughlin, 1996]. Observations on the suitability of agency theory in an accounting history context will be made later in the paper.

In summary, this section has aimed to provide a brief overview of explanations offered by agency and contracting theories for the existence of the independent external audit, and of certain features of audit firms and regulation. The following section explores the development of the audit and audit firms in Germany as a basis for the subsequent discussion of the applicability of the agency theory framework.

\section{THE DEVELOPMENT OF AUDITING AND AUDIT FIRMS IN GERMANY}

Early "Audits": The modern audit in Germany emanated from the internal audit, and the employment by the courts of legal 
experts and professional trustees [Meisel, 1992, p. 39]. The need for internal audit arose in the 15th century with the development of large merchant houses (such as the Fugger and the Welser) and of state-owned companies, and resulted from the physical separation of owners from remote branches of their firms [Meisel, 1992, pp. 35-38]. From the 16th century, and increasingly in the 17th and 18th centuries, external "audits" ${ }^{4}$ were carried out by gerichtlich vereidigte or beeidete Bücherrevisoren (auditors sworn in court). These were expert witnesses in legal disputes [Meisel, 1992, pp. 39-46], who were engaged to review and correct financial information [Henning, 1990].

The first business corporations developed during the 17th century in The Netherlands, France, and England. However, it was not until the second half of the 19th century that the Aktiengesellschaft (AG - public share company) began to dominate the economy in Germany. Its growth was due to increased demand for capital required by industrial expansion, in the transport sector in particular [Meisel, 1992, pp. 60-61]. The early AGs were subject to a Konzessionssystem (licensing system), that is, they required a license and were subject to state supervision [Meisel, 1992, p. 62]. This was the case in the first German law regulating AGs, the Prussian Gesetz über Aktiengesellschaften (Stock Corporation law) of 1843 [Meisel, 1992, p. 61]. Specific accounting and publication requirements for AGs were laid down in the Aktienregulativ of 1856 [Schröer, 1993; Schneider, 1995]. However, there was no legal requirement for an external audit (although internal, or voluntary external audits, were not uncommon [Schröer, 1993]).

${ }^{4} \mathrm{~A}$ brief note is required on the translation of terminology across languages and time. The term "audit" is used here in a wider sense than understood in the context of the modern external audit in the UK or US. However, there are no exact equivalents in translation between languages, and the old German term for auditor does not mean exactly the same as "auditor" or "chartered accountant". Each of these are technical terms that can only be fully understood within their unique contexts. The problem is exacerbated by translation across time. Mills (1989) warns against the possibility that we may be misled by vocabulary in historical contexts. The old German term approximately equivalent to "audit" is Revision (the modern German term (since 1931) is Wirtschaftsprüfung). The texts examined here use the terms Revision and Prüfung, which are treated as synonyms [Meisel, 1992]. Especially during the 1920s, German authors tend to use the terms (Bücher-)Revisor/Revision in translation when they discuss the UK auditor and audit. While German authors were more or less aware of the differences in status, organisation, techniques, etc., they appear in principle to consider the German Bücherrevisor to be comparable to the British auditor [e.g. Raschenberger, 1929; Schwäbische Treuhand-Aktiengesellschaft, 1931]. 
The first company law for all German states was created with the Allgemeines Deutsches Handelsgesetzbuch (ADHGB General German Commercial Code) of 1861. This represented the first codification of the internal organization of the AG regulating the Generalversammlung (general meeting), the Vorstand (management board) and the (optional) Aufsichtsrat $\left(\right.$ supervisory board ${ }^{5}$ ) [Meisel, 1992, p. 63]. The latter, if appointed, was responsible for monitoring management and the auditing of the accounts [Article 225]. The law was reformed in 1870 [Gesetz betreffend die Kommanditgesellschaften auf Aktien und die Aktiengesellschaften]. Changes included the removal of the licensing system and its replacement by a new Normativsystem ("normative" system). This meant AGs no longer required licensing by the state and were no longer subject to state supervision [§ 2 Article 249a; see also Quick, 1990; Meisel, 1992, p. 63] but instead, once registered, they were subject to general rules and regulations. The new regulation was intended to provide better protection for shareholders; the individual company should be subject to continuous supervision and control through its owners [Reich, 1979]. The supervisory board became obligatory; it had to consist of at least three members selected from the shareholders [§ 1 Article 209 (6)]. Article 225a required that the supervisory board monitor the management of the AG. It also gave its members rights of access to documents and information, required them to audit the accounts and proposals for profit distribution and to report to the annual general meeting [ibid., see also Klausing, 1933, pp. 172-173; Karoli, 1934]. The members of the supervisory board were jointly and severally liable for certain breaches of the law such as the unlawful distribution of profits [Article 225b]. The board would at times employ professional auditors to fulfill their duties [Quick, 1990].

Advancing industrialization and the financial inflow of French reparations after the Franco-Prussian War of 1870-1871 contributed a dramatic increase in company formations and corporate expansions and mergers [Meisel, 1992, p. 64]. Associated with these changes was the increasing separation of ownership and control and growing shareholdings by banks [Gietzmann and Quick, 1998, p. 88]. Easier access to the vehicle of the AG, and its de facto weaker regulatory system, appears to

\footnotetext{
${ }^{5}$ The two-tier board structure, which remains a feature of modern German public companies, allows different stakeholder groups to be involved in the governance of the firm.
} 
have been one of the factors leading to the subsequent economic crisis of the early 1870s (Gründerkrise) which was associated with increased formation of AGs, bankruptcies, liquidations, speculation and fraud [Reich, 1979; Meisel, 1992, p. 63]. The extant law was too vague in its requirements regarding the supervisory board's monitoring duties, and supervisory board members often failed to perform even these duties. Their boards' understanding of financial statements was also doubted [Gietzman and Quick, 1998]. Further, the growing involvement of supervisory board members in the management function threatened their independence [Karoli, 1934], thereby "calling into question whether there did in fact exist an independent two-tier form of corporate governance" [Gietzmann and Quick, 1998, p. 88].

The crisis during the 1870 s led to calls for the introduction of a statutory audit [Haibt, 1998]. This demand was not met when the law was further amended in 1884, in the form of a new Gesetz betreffend die Kommanditgesellschaften auf Aktien und die Aktiengesellschaften. ${ }^{6}$ The new law extended the rights and duties of the supervisory board regarding monitoring, auditing and reporting. ${ }^{7}$ The general meeting or, under specific circumstances a minority of 10 percent of the shareholders, could demand the appointment of external auditors [\$1 Article 239a]. The 1884 law did introduce one form of compulsory audit - an audit of the company formation process by the supervisory board and the management board. Article 209h, which dealt with this

${ }^{6}$ The Begründung (explanatory memorandum) to the 1884 law is an interesting source of data regarding company foundations and failures from 1870 . Before the 1870 law, Prussia had a total of 203 AGs. A further 843 new AGs were founded in the following three years alone. The memorandum laments the fact that the average (initial) share capital of the AGs had fallen from almost 11 million Marks among the old AGs to a third of this, and that some AGs had share capital of less than 100,000 Marks. Many of the new AGs were conversions of private enterprises, rather than new company foundations [Begründung]. Frauds had apparently been expected to follow the change from the licensing system, but not to the extent that they actually occurred [ibid.]. The abuses of the system led to serious consideration of the abolition of the legal form of AG [ibid., p. 242].

${ }^{7}$ For example, Article 225 (translation) states that "the members of the supervisory board may not delegate their duties to other persons". Article 225a prohibited the same individuals from being members of the supervisory board and management board. Article 226 made the members of the supervisory board and management board jointly and severally liable for damages arising from the breach of certain legal provisions. 
audit, required the appointment of besondere ("special"), external auditors where members of either board were also founders of the company, had made contributions in kind to the company, ${ }^{8}$ or had negotiated particular advantages for themselves [see also e.g. Beigel, 1924; Karoli, 1934, see also below]. The benefit of this audit was subsequently questioned because the "clients" were the company founders, who would have been in a strong position to influence the auditors [Hintner, 1926, p. 21; see also below].

Apart from these specific audit provisions, the external audit remained voluntary. The law assumed the competence and integrity of the supervisory board and the intelligence of the general meeting, with its potential power to appoint independent auditors [Quick, 1990]. However, this right was rarely used, "since it was generally perceived that this might signal to the financial community that the organization was experiencing financial difficulties" [Gietzmann and Quick, 1998, p. 88]. The general meeting had been intended as the highest decisionmaking organ; in practice it did not fulfill this expectation [Reich, 1979]. Further, after the 1884 law, the supervisory board was still perceived to be an impossible hybrid, and remained involved in the companies' management and/or did not meet its control function [Karoli, 1934; Reich, 1979]. Its members continued to lack the necessary expertise and time required for effective monitoring. While the board often drew on the services of professional auditors, this did not happen in all cases.

One interesting and far-reaching change implemented by the 1884 law was the raising of the minimum value of a share to 1000 Mark [Article 207a]. This effectively closed the AG to small and medium-sized enterprises and made it the typical legal form of large enterprises. It also led to the increasing role of banks as providers of capital [Reich, 1979]. The lack of access to the limited liability legal form for small and medium-sized enterprises resulted in the creation of the Gesellschaft mit beschränkter Haftung ( $\mathrm{GmbH}$ - private limited company) in 1892.

A new Handelsgesetzbuch (HGB - Commercial Code) in 1897 introduced few new accounting and auditing rules [Schröer, 1993], although §§ 192-194 somewhat strengthened the position of those charged with the audit of the foundation

\footnotetext{
${ }^{8}$ Sacheinlagen ("contributions in kind") rather than Bareinlagen ("cash subscriptions").
} 
process. ${ }^{9}$ While conceding that this audit had proved successful, Voß [1927, p. 17] argued that the legal provisions were not sufficient to ensure that the legislator's intentions had been met, in particular because the audit was usually carried out by the companies' management and the supervisory boards, and only under specific conditions by "special" auditors. Voß considered this to be a defect in the law, frequently used as a "loophole", which allowed companies to circumvent the requirement to appoint external auditors. For example:

Straw men have been placed onto the management board or supervisory board; that has in fact happened, for example when auditors had been appointed by the chamber of commerce, who did not suit the company concerned, or one has - and that is the main point at issue - set up a so-called veiled Sachgründung [company formation based on non-cash capital contributions]; that is, initially a company was founded through Bargründung [company formation by cash subscription], but it was planned from the start that this company should purchase certain assets - the Sachgründung was therefore carried out as the second step, by a detour [ibid., translation, see also footnote 8].

Such cases of deliberate deception apart, the perception was that the control function of the supervisory board had not improved since the 1884 law. Römer [1905, p. 262, translation] complained: "How can somebody who holds 35 supervisory board positions or who has never seen a book of account, let alone kept one - and we have such supervisory board members! - be able to discharge their incumbent statutory duties of control?"

Apart from the compulsory audit of the company foundation process, approximately $60 \%$ of German AGs were, by the 1920 s, undergoing either a form of internal or voluntary external audit [Klausing, 1933, pp. 173-174]. ${ }^{10}$ It appears though that

\footnotetext{
${ }^{9}$ It described what specifically was to be audited and dealt with potential conflicts between auditors and founders, which had to be decided by the responsible chamber of commerce [see also Gareis, 1900, pp. 180-184 and Hintner, 1926, pp. 20-21]. Further, the auditor was granted the right of access to all books and records, cash balances, stock etc. [§ 267, 1; see also Hintner, 1926].

${ }^{10}$ Leffson [1988] estimates that by 1900 almost $60 \%$ of German AGs were voluntarily undergoing an external audit. An internal audit would have been carried out by members of the supervisory board or employees of the auditee, i.e. by parties who were not independent. An external audit, on the other hand, would have been performed by an independent individual or company carrying
} 
initally the external audit was of limited benefit and mainly consisted of a comparison of the accounts with books and records [Quick, 1990]. Many enterprises which would have benefited from an independent external audit due to the limited competence of their management were either not audited or arranged for a "Scheinrevision". The latter referred to an audit opinion which was "bought" from "so-called" auditors in order to present the appearance of orderly accounting and management, until the company finally collapsed [Klausing, 1933, p. 174].

Auditors and the Emergence of Audit Firms : External audits were mainly carried out by vereidigte Bücherrevisoren (sworn in auditors) and notaries [Meisel, 1992, p. 76]. Originally the Bücherrevisoren $(\mathrm{BR})^{11}$ were sworn-in by the courts only in relation to specific appointments, but during the second half of the 19th century they were increasingly granted this status on a permanent basis. In 1895 approximately 140 individuals were thus licensed in Germany. A further 20 auditors were appointed by the chambers of commerce of the cities of Hamburg, Bremen and Lübeck [Penndorf, 1932; Meisel, 1992, p. 91]. In 1900 the Gewerbeordnung (Trade Regulations Statute) was amended to permit the licensing of auditors by authorities other than the courts, most notably the state and the chambers of commerce [Klausing, 1933, p. 174; Meisel, 1992, pp. 94-95]. However, questions regarding the quality of some of the individuals thus appointed soon arose [Quick, 1990]. For example, there appears to have been a lack of commercially educated, independent BR fully conversant with double entry [Klausing, 1933, p. 174].

Although audit work was only part of the BRs' work [Römer 1905, pp. 119-120], at around the turn of the century they began to face competition from the new Treuhandgesellschaften (THG trust companies). The first such company was the Deutsche Treuhand Gesellschaft (originally: Deutsch-Amerikanische Treuhandgesellschaft), which was founded in 1890 and based on the example of American trust companies [Meisel, 1992, pp. 67]. The Deutsche Treuhand Gesellschaft was founded by the

out similar work for other clients (but see below regarding the problem of firms related to the auditee). As it was voluntary, the scope of the audit would have varied, depending on the supervisory board's requirements. The auditors would have reported to the supervisory board, which may have referred to the auditors' report in its report to the General Meeting.

${ }^{11}$ In 1943 the name was changed to vereidigte Buchprüfer. 
Deutsche Bank AG, the Bankhaus Jacob S.H. Stern and others, and was intended as a finance and trust company for the benefit of shareholders in foreign enterprises [Hintner, 1926, pp. 14-15, 115; Meisel, 1992, p. 7]. After 1900 the Deutsche Treuhand Gesellschaft was often involved in company reconstructions, which usually required the help of auditors ${ }^{12}$ and it soon developed its own audit department. When economic conditions improved and company reconstructions became rarer, this audit department made its services available to the general public [Meisel, 1992, p. 7; Haibt, 1998]. The audit was offered as a preventative device, a periodic control to support the monitoring function of the supervisory board. The audit was utilized to assess potential threats to the financial stability of the company and determine how these could be averted [Henning, 1990], and thus to prevent company collapses [Hintner, 1926, p. 16]. Hintner [ibid.; with reference to Lansburgh, 1908] points out that this function was very successful. The Deutsche Treuhand Gesellschaft carried out 27 such external audits in 1903, 70 in 1904, and more than 400 in 1907.

From 1906 auditing was the Deutsche Treuhand Gesellschaft's main activity [Hintner, 1926, p. 59; Rosendorff, 1906]. Its success led to the formation of similar companies, especially by banks [Haibt, 1998; see also Klausing, 1933, p. 174]. By the early 20th century audit work was the main occupation of many THGs [Haibt, 1998], but in spite of the firms' changing remit their old organizational and legal forms were retained. They also became the model for new THG foundations [Hintner, 1926, p. 119]. While company collapses in 1900-1903 led to renewed pressure for the introduction of a statutory external audit, the foundation of the THGs initially appears to have abated this. The numbers of BR and of audit THGs increased considerably. However, a lack of formal regulation of the emerging profession meant that there was no control over quality, and there was concern that poorly qualified individuals might damage the reputation of those more competent to perform audits [Gietzman and Quick, 1998]. Römer [1905, p. 270, footnote 1, translation] complained:

${ }^{12}$ They had to establish firstly whether a successful reconstruction was possible, then may have been involved in carrying out regular audits, i.e. to attest the accounts in order to establish, for example, whether conditions imposed by creditors were complied with [Hintner, 1926, pp. 15-16]. 
How Bücherrevisoren are sometimes "trained" in Germany and Austria, or how it is at least attempted to "train" them is shown by the following two advertisements, of which one was repeatedly published in Austrian, the other in Berlin papers:

No. 1. "For 50 Marks anybody can [train to] become a good Bücherrevisor with me. If he does without instruction in Geschäftswesenheit (!), ${ }^{13}$ including commerce and Aktiengesellschaft, and without the trial audit of forged company accounts, the fee only amounts to 30 Marks!" - No. 2. "Audit course including exam and diploma 30 Marks!" - Is that not more than shameful? I have often been asked by young and old people how to become Bücherrevisor in Germany, and I have only ever had one answer: "By accident!" That such a state is unworthy of Germany does not need saying.

Another statement from a provincial newspaper highlighting the same problem also appears in Römer [1905, p. 271, footnote 1, translation]: "Warning! Recently unemployed individuals, who understand neither double entry bookkeeping nor accounts preparation, have frequently been promoting themselves as Bücherrevisoren. Are they "Bücherrevisoren"? When will this issue be remedied?"

From the end of the 19th century, and especially during the first decades of the 20th century, common standards for audit work and standardized fee rates were developed [Beigel, 1924, p. 43]. Further, a number of professional associations were formed, representing the THGs and the BR respectively [Meisel, 1992, pp. 129-150; Markus, 1997, p. 3-9; Haibt, 1998]. These included the Verband Deutscher Bücherrevisoren (VDB) which was founded in 1896. It was hoped that membership of this association would raise the reputation of its members [Penndorf, 1932]. ${ }^{14}$ The Verband Deutscher Treuhand- und Revisionsgesellschaften was created in 1920 in order to represent the interests of the smaller THGs not linked to banks. The fact that the small audit firms created associations effectively forced the larger firms to do the same in order to be able to represent their interests before relevant authorities and the public. Thus

\footnotetext{
${ }^{13}$ Note that this is not a meaningful term in German. In general the German in the original advert is poor.

${ }^{14}$ According to Hintner [1926, pp. 54-55], by 1925 the VDB had 842 members, while the number of sworn-in BR active in Germany at about this time was estimated as approximately 2000 .
} 
the Reichsbund Deutscher Treuhand-Aktiengesellschaften was created to represent the large THG AGs [Hintner, 1926, pp. 82-84].

Although pursuing contrasting agendas in other respects, the different associations united in their demand for the legal regulation of the external audit [Meisel, 1992, pp. 151-167; Markus, 1997, pp. 12-13]. They were supported in this by the banks, the legal profession [Quick, 1990; Haibt, 1998], academics and the trade press [Klausing, 1933]. At the same time demands were made for standardized regulation of the education, training, appointment and licensing of members of the audit profession [ibid.]. By 1924 the VDB had drafted suggestions for legislation governing the regulation of the audit and the educational, ethical and other criteria for entry to the profession. A second version was later drafted jointly with representatives of other associations of BR. However, both these attempts were rejected because of concerns that they were intended to protect the interests of the BR by implementing restrictive practices detrimental to the public interest [Gietzmann and Quick, 1998, pp. 88-89]. Voß [1927, p.1, translation], a syndic of the VDB, and thus an interested party, commented as follows:

... the discussion of the problem in the public domain has been infected by the most diverse interests. One can choose to retain the corporation law in its current content, one may choose to reform it, in any case economic interests are at risk, which appear to be diametrically opposed and whose representatives in turn, and in excluding each other, claim their interests alone represent those of the public.

Thus the diverging interests of the various professional groups comprised an obstacle to the regulation of the audit and the profession [Klausing, 1933, p. 176]. Their views on how the profession should be controlled differed considerably, on issues such as legal and organizational forms, self-regulation or statecontrol, and the regulation of education, training and licensing [see also Meisel, 1992, p. 151]. Other (and earlier) arguments against the introduction of the statutory audit related to a perceived lack of suitably qualified auditors [Klausing, 1933, pp. 175, 177]. Weber-Boun [1904, p. 30, translation] compared inter alia the training of British accountants with the situation in Germany. He concluded that Germany was not ready for regulation because "suitable individuals in sufficient number are not available, a shortfall which at best could only be corrected in a number of years". 
The lack of comprehensive regulation of the audit resulted in a reluctance by foreign lenders and investors to provide capital to German firms unless they had been audited by the lenders' or investors' own auditors [Markus, 1997, pp. 13-17; Haibt, 1998]. Foreign capital was required as a result of the economic crisis following World War I. This led a number of Anglo-American audit firms to establish branches in Germany [Markus, 1997, pp. 14-17]. It also gave rise to suggestions to introduce an external audit based on Anglo-American models (which were rejected) [Haibt, 1998]. However, the economic crisis of the 1920 s led to renewed pressure for the introduction of the statutory audit [Meisel, 1992; Quick, 1990; Haibt, 1998]. It also encouraged increasing state intervention in the economy. In 1925 the state-owned Deutsche Revisions- und Treuhand-AG (Treuarbeit) was created, which increasingly carried out audits of enterprises in which the state owned shares, and additionally gained appointments through the representatives of private enterprise on its own supervisory board. Many of these audits had previously been carried out by BR working as sole-proprietors or in small firms [Haibt, 1998, p. 33].

By the late 1920s the German audit (at its best) had developed from being a formelles ("formal") audit, concerned with presentation and legal compliance, to a materielles ("material" or "substantial") audit, concerned with examining the economic validity of measurements and valuations and assessing the situation of an enterprise as a whole [Schwäbische TreuhandAktiengesellschaft (Schitag), 1931]. However, until it was regulated by law, the scope of the audit remained under the control of the supervisory board which commissioned it, and was often limited [Schitag, 1931]. The state still hesitated to introduce reforms until spectacular collapses took place between 1929 and 1931 (especially that of Favag, summer 1929). These convinced the legislature that the control function of the supervisory board and the voluntary or internal audit were insufficient, that the audit profession required regulation, and that a compulsory annual audit was required [Klausing, 1933, p. 177].

Further, by this time the different associations of BR and THGs had, after long negotiations, jointly founded the Institut für das Revisions- und Treuhandwesen (August 1930), which in early 1932 became the Institut der Wirtschaftsprüfer [ibid.]. The statutory audit was finally introduced (although initially only for very large companies), the profession of Wirtschaftsprüfer (WP) formally "created", and additional accounting and publication requirements implemented with the reform of the corporation 
law through the presidential decree Verordnung des Reichspräsidenten über Aktienrecht, Bankenaufsicht und über eine Steueramnestie in 1931. The new law contained specific rules on the appointment, independence and rights and duties of the auditor [Quick, 1990; see also Meisel, 1992, pp. 168-203; Markus, 1997, Chapter 2].

Bücherrevisoren versus Treuhandgesellschaften: As indicated above, the differing objectives and ensuing power struggle between the two "faces" of the profession, the BR and the audit THGs, encouraged regulation by the state and contributed to the delay in introducing the statutory audit. Disputes between the groups centered on two main issues: the THGs' increasing share of the audit (and related services) market, to which their link with the banks and/or state was a contributing factor, and the question of organizational and legal forms. In relation to the latter, the question arose as to whether a corporation (AG or $\mathrm{GmbH}$ ) could be a suitable legal form for the so-called freie Berufe ("free professions") ${ }^{15}$ with their ideologies of independence, public service, responsibility, and individual judgment. Two publications in the 1920s illustrated the different positions - Beigel's [1924] Lehrbuch (teaching textbook) on accounting and auditing contained a political condemnation of the THG audit corporations, which he considered reflected the political agenda of capitalism. Beigel considered THGs to be "obedient servants of capitalist-speculative interests" [ibid., pp. 14, 52]. Hintner's [1926] more moderate Habilitationsschrift ${ }^{16}$ stressed the advantages of the bank-owned THGs. He distinguished three types of audit THG AGs: bankmässig orientierte (those owned by banks); erwerbsmässig orientierte (those founded by individual or small numbers of $\mathrm{BR}$ ), and; konzernmässig orientierte (those founded by commercial enterprises/groups) [ibid., 1926, p. 60]. ${ }^{17}$

One of the important differences between the different types of legal forms and sizes of audit firms related to their financial capital. On behalf of the large bank-owned THGs it was argued that their share capital, which was usually considerable,

${ }^{15}$ For a discussion of the differences between the terms "profession" (in the UK) and "freie Berufe" (in Germany) see Vieten [1995, p. 487] or Kocka [1990, p. 62].

${ }^{16}$ Second thesis required of those aspiring to an academic career.

${ }^{17}$ At around Hintner's time of writing there were 22 bankmässig orientierte THG AGs, 85 erwerbsmässig orientierte THG AGs, and 12 konzernmässig orientierte THG AGs [ibid., pp. 62-78]. 
provided a security or bond against damages caused by auditors' mistakes. ${ }^{18}$ The reputation of the associated banks themselves, as well as that of the audit firms, also provided a source of nonfinancial security. An established audit corporation had incentives to avoid damage to reputation as much as an individual practitioner. The reputations of the management and supervisory board members offered an additional bond. This provided incentives for the large firms to implement careful personnel and monitoring policies. The konzernmässig orientierten THGs, especially if older, also often had a reputation which could act as security. But, according to Hintner [1926] the share capital, and thus the financial bond, was considered to be too low. ${ }^{19} \mathrm{He}$ suggested that the title THG AG might have been intended to mislead the market as to the size of the enterprise.

According to Beigel, it would have been impossible to sue auditors for errors, because the law held the supervisory board solely responsible and liable for the supervision of management [see HGB $1897 \S \S 246-249]$. In his view, the financial bond was, therefore, of limited significance. He further stressed that the audit was carried out by employees of the corporations. An error by one of these employees would have led to a reprimand or perhaps dismissal, but did not threaten the existence of the corporation. While the unincorporated sole practitioner had no large financial bond to offer, Beigel [1924, pp. 31-32, 52-53] stressed that the loss of reputation might have meant the loss of one's livelihood. Hintner conceded that the sole practitioner, with his personal liability, provided a stronger bond than the small THG AGs, whose owners risked only their share capital and damage to the reputation of the firm. Both corporations and individuals could increase the guarantees they provided through insurance, but it was not always easy for individual auditors to obtain such cover [Hintner, 1926, p. 94].

One of the strongest perceived advantages of the BR was the personal relationship of trust with the client. This was linked to

${ }^{18}$ Hintner also pointed out that it was common for only $25 \%$ of the share capital to be paid up. This suggests that it was mainly intended as a security for the client rather than being required for the running of the company.

${ }^{19}$ For example, he considered RM 5,000-10,000 to be too low. For the bankrelated THGs the share capital ranged from RM 5000 to RM 1,200,000, with an average of approximately RM 120,000. For the erwerbsmässig orientierten the average was less than RM 40,000 and for the konzernmässig orientierten RM 157,000. Note that these sums cannot be compared with those in footnote 6 because, following the hyperinflation of the early 1920s, a new currency, the Rentenmark (RM, later Goldmark) was introduced in 1923. 
personal liability. The relationship between the employees carrying out audits on behalf of the THGs and the THGs' clients was less strong. Hintner considered this to be an advantage, because it strengthened independence. Further, large THGs attempted to provide continuity in the staff that served particular clients, in order to create personal trust relationships similar to those offered by the sole BR. They had, however, the opportunity to rotate staff if necessary to protect independence [Hintner, 1926, p. 94]. BR also relied on employees to carry out audit work on their behalf. Beigel [1924, p. 54] argued that they merely used their employees, under supervision, to carry out minor tasks while the employees of the THGs used a formulaic approach, and the audit report was signed by the THGs' directors without any audit work being reviewed in detail.

A further controversial point was the competence and skill available to the different types of audit organizations. The knowledge and abilities of the BR varied considerably. According to Hintner, many did not have the necessary skills. Voß [1927] lamented the fact that, while BR appointed by state or regional authorities (such as the chambers of commerce) were subject to some degree of regulation and disciplinary sanctions, in general the title Bücherrevisor was not protected. Anybody could call themselves Bücherrevisor, found an audit firm and carry out audit work, without having to provide any evidence of suitability for this work. Voß stated: "It is no secret that there are many among these individuals who have a criminal record or who otherwise had a shady reputation and who are probably least likely to be suited, in particular for such a trust-based profession as that of the auditor" [ibid., p. 29, translation]. Being formally licensed was thus a desirable goal for sole practitioners because it would raise their reputation in the eyes of the public [Hintner, 1926, p. 53]. However, there seemed to be little consistency in what was required of BR by the chambers of commerce. Hintner [1926, p. 23] points out that the strong position of the THGs in the audit market was partly due to the fact that they had access to better trained personnel than was the case for the BR and their larger capital base permitted them to obtain better staff and allow a certain degree of industry specialization. Further, more experienced staff could leave routine tasks to their assistants. Also, a separation of audit from closely related work would not be feasible nor desired by clients. Thus a knowledge of both tax and legal matters was required, which could be more easily provided by the larger firms.

One of the main criticisms of the THGs concerned auditor 
independence. It was argued that the audit firms founded by banks and commercial/industrial groups lacked independence from their clients. Clients often belonged to the same group and were given little choice in the appointment of auditors. So, for example, Römer [1905, p. 138, translation] stated: "It is probably of more concern that the German Treuhandgesellschaft as auditor cannot be considered independent according to the English meaning: it should not have pitched its tent in the palace of the Deutsche Bank and should have turned towards the pure banking business less energetically!"

Hintner [1926, p. 100] by contrast, argued that attacks on the independence of the bankmässig orientierten THGs were unjustified, because the banks would have no interest in influencing an audit opinion (but see below). With regard to the konzernmässig orientierten THGs he argued, though, that the audit was merely equivalent to an internal audit function, as audit clients were owners (and members of the supervisory board) of the audit firm and could thus influence the scope of the audit and the audit process. This might not have been known to external shareholders of the auditee [ibid., pp. 100-101]. ${ }^{20}$ On the other hand, the more substantial capital base of the large THGs strengthened their independence because it rendered them less dependent on the fees of an individual client [Hintner, 1926, p. 95]. Theermann [1930, p. 43, translation], a director of a THG AG, claimed that bank-owned audit firms were less dependent than the firms without such links because the latter were economically dependent on those who made appointments:

I would even like to claim that a bank audit firm often faces the auditee more "independently" in that it receives the audit appointment directly from the supervisory board and does not have to make an effort with the auditee to obtain the appointment. ... many "free" auditors are finding themselves in the most difficult personal economic struggle and for this reason very often are "unfree" when facing their clients. Many criminal court cases of recent times give a sad verdict on this.

A concern related to the lack of independence was client confidentiality. Beigel claimed that THGs would breach confidentiality by disclosing sensitive information to the banks with which they were linked:

${ }^{20}$ See also Klausing, 1933 , p. 241, for a critique of the apparently common practice to disguise or window dress such links between auditor and auditee. 
To the outside these companies present themselves as independent organizations, and the firms which place themselves, with their books and balances, into their care for the purposes of auditing appear not to know that a double role is taken in this, in that the results of the audit are presented to the client; then however also the bank ${ }^{21}$ will receive a report regarding the turnover, credit and asset situation, in short covering everything which may be of interest to it. In suitable cases the audit firm receives particular instructions from the bank regarding which points to keep a special eye on during the audit [Beigel, 1924, pp. 22-23, translation].

Further: "Businessmen as well as Aktiengesellschaften have repeatedly complained about the fact that private commercial activities had become known to non-authorized agencies" [ibid. p. 24, translation]. ${ }^{22}{ }^{23}$ However, Hintner [1926, pp. 121-127] disagreed and claimed that many THGs had developed internal rules to prevent breaches of client confidentiality.

Part of the objection to the corporate form appears to have been related to the THG AGs' large size. The GmbH is a corporate form more suitable for small and medium-sized enterprises and has a lower minimum capital requirement. Share ownership is not anonymous and can be more easily monitored and controlled. According to Hintner [1926, pp. 81-82] the number of $\mathrm{GmbH}$ audit firms increased dramatically after World War I, but many disappeared just as rapidly. Hintner considered this legal form unsuitable because it lacked the financial backing to provide security, no longer guaranteed the personal relationship with the client which the sole practitioner offered, and was not publicly accountable. Further, the auditor was usually the

${ }^{21}$ Beigel uses the term Großbank (lit.: "large/major bank").

${ }^{22}$ As further evidence Beigel [1924, pp. 28-29] quotes as follows from the journal Die Bank: "Concerning the fees which the audit firms are claiming ... the costs of the audit are that highly calculated, that really only candidates for company foundations can normally afford the luxury to charge an audit firm with the audit of its management. A number of years ago, for example, the Deutsche Treuhandgesellschaft was involved in a court case because a foundry would not accept its fees $(500 \mathrm{M}$. for the first, $100 \mathrm{M}$. for each of the following days). Later, incidentally, the fees of some firms were somewhat reduced. It showed that knowledge of others' balance sheets brings so many indirect advantages, that a little bit of fee income more or less is not relevant" [Buxbaum, 1910, quoted in Beigel, 1924].

${ }^{23}$ It was alleged, for example, that banks founded audit THGs in order to use them to identify investment targets. This claim is dismissed by Hintner [1926] as crude and unfeasible, and as not justified by the behaviour of the banks. 
founder, shareholder and director, while friends or family members formed the management board. No supervisory board was required. In other words, no monitoring or control needed to be provided [ibid.]. Some GmbHs attempted to enhance their reputation (and bonds) through membership of professional associations. Size-related advantages of the THGs meant that the big firms were often more suitable for larger clients and that higher staff numbers allowed better mutual monitoring and control, as well as specialization and the ability to tackle larger appointments (see above). On the other hand, the larger THGs would be less profitable than sole practitioners because salaried staff commit resources; high salaries were necessary to attract and retain quality staff. The larger THG also incurred greater overheads [Hintner, 1926].

From the early 1900s onwards, but especially in the second and third decades of the 20th century, the audit market, which had initially belonged exclusively to the BR, became divided: the bankorientierten THGs were mainly involved in audits of companies in which banks had invested and were represented on the supervisory boards, i.e. their appointment was not a voluntary choice by the client. The small private business, on the other hand, preferred the BR as auditor, because relationships of personal trust with an individual were more important. The secured market share of the THGs restricted the BRs scope for expansion. Competition for the independent sole practitioner also arose from the foundation of small independent THGs, which were unable to compete in the market with the larger bank- and group owned THGs and instead pursued the audits of smaller enterprises [Hintner, 1926, pp. 128-127].

\section{DISCUSSION}

The Audit Requirement and Professionalisation: An examination of the development of the corporate audit in Germany reveals early similarities with the experience of the UK. For example, the internal audit contributed to the development of the external audit; early audits were carried out by shareholder/director committees; the development of the audit profession predated the statutory audit requirement; voluntary audits predated regulation, and; the profession attempted to introduce some degree of self-regulation. For Watts and Zimmerman, such features provide evidence in support of contracting theory. Nevertheless, it appears that despite the above parallels, auditing, the audit profession, and audit firms developed differently in Germany. 
For example, it is usually suggested that the "modern" German profession was created by the state, while the UK profession was created by practitioners [see Vieten, 1995, pp. 504, 487]. Also, the earliest associations of accountants in Britain were officially recognized (through Royal Charter) eighty years before the German profession achieved a similar status through state recognition [ibid., p. 494].

Perhaps the most important causes of differences relate to the respective economic contexts, particularly the growth of joint stock corporations [Matthews et al., 1998, p. 242]. Hintner [1926, p. 137] claimed that in England, ${ }^{24}$ unlike in Germany, no fixed share capital had to be raised to found a corporation, and that the existence of much private wealth enabled enterprises to raise capital from investors without the help of banks. The British capital market always differed from that of other European countries because: "it started earlier, benefited from the ready availability of local finance, was granted a cheap and easy mechanism for incorporating with limited liability, and operated in a laissez-faire environment in which the audit was the main safeguard that the market, through contractual arrangements between investors and management, came to insist on" [Matthews et al., 1998, p. 245].

These factors are related to a further important difference, namely the respective corporate governance arrangements. In Germany, companies were traditionally financed by banks, and the banks were usually represented on companies' supervisory boards. Thus the banks had a much closer involvement with corporations, including the company formation process, than was the case in the UK. Banks (in theory) exerted a degree of monitoring over their investments from which other stakeholders benefited [Hintner, 1926, p. 136; see also Gietzman and Quick, 1998]. The foundation by the banks of the audit THGs was a means to facilitate such monitoring [Hintner, 1926, p. 137]. In the UK and US, by contrast, management motivation was (and is) effected through "a market for corporate control" and fear of takeovers [Gietzmann and Quick, 1998, p. 83]. Hintner [1926, pp. 130-136] suggested that the audit developed more slowly in Germany than in England because German law provided better protection for shareholders and creditors through provisions relating to the supervisory board, accounting

\footnotetext{
${ }^{24}$ Note that German authors frequently focused specifically on England, or used the term "England" with reference to the whole of the UK.
} 
and publication requirements, and minimum share capital. Therefore the need for an audit would only have been felt in exceptional cases, such as when there was suspicion of fraud or other particular problems were being experienced. The British law, however, lacked the protection for shareholders provided by the German law, and shareholders created their own protection by demanding an external audit. Therefore, according to Hintner [ibid., p. 136], the re-introduction of the statutory audit in the UK in 1900 was merely the codification of existing practice. On the other hand, with the exception of the bank initiatives, due to the form of corporate governance the demand for the audit in Germany was limited, and this restricted the growth of the audit industry [ibid., p. 129]. Further, as discussed above, in Germany the auditors' reporting responsibilities were to the supervisory board rather than to the shareholders, and the scope of their work was usually more restricted [Gietzmann and Quick, 1998, p. 85].

A further difference relates to the role played by the state in the professionalization process. While in the UK professions tended to develop "spontaneously" as a result of initiatives by voluntary associations, in Germany they were created as a result of "reform from above" through state initiatives [Neal and Morgan, 2000, pp. 9, 46]. Parliamentary democracy developed in Germany later than in the UK, and the reforms of the Napoleonic regime continued to shape administration and jurisprudence [ibid., p. 21]. The result of this was that "bureaucratic authority and constitutional government developed hand in hand", "social reforms were the result largely of the civil service rather than any popular movement" and "[i]n Germany professional practitioners were far more inclined to look to the state to organize and regulate the professions" [ibid., p. 9]. ${ }^{25}$ For example, Hintner [1926, pp. 141-166] argued that the audit profession should be subject to formal external supervision. Given its authoritarian nature the support of the state was required. However, in spite of the German profession's efforts to obtain regulation, the state remained reluctant. Gietzman and Quick [1998, p. 90] speculate that this may have been because the members of the profession were unable to "credentialize their expertise" and

${ }^{25}$ The most popular means of organising associations was in the form of Vereine (associations, societies), which are regulated by law and require registration and approval of their articles. This permits the authorities to control the associations' activities [Neal and Morgan, 2000]. The associations of auditors were generally registered as Vereine. 
that therefore the profession chose a deliberate strategy of involving academic and state bureaucracies in their development. As a result these bureaucracies, including higher education, became more influential and led the profession to develop with a different identity from those in Anglo-American countries [ibid.]. In consequence "German auditors found it less problematic to view the state and thus society as in part constituting the client, unlike the more parochial view of British auditors" [ibid., pp. 90-91].

Education also formed part of the German and British professions' differing strategies. In Germany, business schools were founded as early as 1898 - the Handelshochschule in Leipzig was the first and offered a course for auditors in 1907. Others soon followed [Karoli, 1934, p. 23]. In the UK, initiatives to introduce accounting at universities remained rare: "the subject was largely ignored by British universities while, for their part, the accounting associations remained entirely committed to their own pupillage and examination system of qualification" [Matthews et al., 1998, p. 260].

Vieten suggests that when the state eventually intervened in Germany, the recognition of the auditing profession was an attempt to control companies and to allow the state to protect the economic system and society in a much wider sense than was the case in the UK where the emphasis was on the protection of shareholders and creditors. According to Neal and Morgan [2000, p. 20; also Vieten, 1995, p. 487], given the governments' laissez-faire policies, the professions in Britain would have been expected to regulate themselves, as there were few ${ }^{26}$ precedents for state regulation. Thus professional status was linked in Britain to membership of elite organizations, rather than to state recognition, as was the case in Germany. The creation of associations also provided a limited safeguard against competition.

In summary, and with reference to the agency theory assumptions outlined earlier in the paper, it can be concluded that a separation of ownership and control existed in German enterprises before, and increasingly after the development of the AG. This appears to have been the case to a lesser extent than in the UK for two reasons. Firstly, there were fewer public companies. Secondly, companies were financed differently, by financial institutions rather than individual external shareholders [see Zysman, 1983]. The financial institutions were represented

${ }^{26}$ Rare exceptions existed (for example, medicine). 
on companies' supervisory boards, were thus party to inside information and in a position to monitor management's behavior. This reduced the separation between ownership and control and the pressure for financial reporting and the independent external audit as means of discharging the manager-agents' accountability. This indicates that existing agency problems were not tackled in the same way in Germany. Monitoring was supposed to be carried out by the supervisory board. As late as 1930, von Falkenhausen (a lawyer, 1930, p. 442, translation) commented critically: "It is thought that the English regulations can be implemented into German law, without considering that the "auditors" of the English law have to fulfill a large part of the functions of the German supervisory board. ... a new independent control organ [would] have no separate scope, its powers would overlap to a large extent with those of the supervisory board".

For monitoring to lead to a reduction of agency costs, the market (or the principal) has to be convinced of the monitoring agency's competence and independence. However, the supervisory boards were consistently criticized for their members' lack of expertise and involvement in companies' management. The explanatory memorandum to the 1884 Gesetz betreffend die Kommanditgesellschaften auf Aktien und die Aktiengesellschaften actually argued that some involvement by supervisory board members in the management activities of the company would enable them to better meet their supervision and monitoring duties [p. 289]. However, this involvement became increasingly problematic, especially when finance from non-German sources was required and foreign investors had to be attracted. The supervisory boards began to appoint professional auditors to help with the discharge of their responsibilities. The external audit also struggled to convince the market of the auditors' competence and independence. In particular the smaller BRs seemed to suffer from a poor reputation regarding a lack of competence, or at least a perceived lack of consistency in the quality of the service provided. They were further unable to serve larger clients and to compete in a market increasingly controlled by complex groups, including influential banks and their related audit firms. The majority of the larger THGs, while perhaps able to offer a better quality product, suffered from a lack of independence. They could certainly not be considered as independent in the sense expected of British auditors [see Römer, 1905, quoted above]. However, with the exception of foreign investors, there appears to have been less need to convince the market, as 
a market share was guaranteed through group structures and networks. It appears that the audit was only one of a number of ways of dealing with agency problems, and that the supervisory board remained the main mechanism, supported by more detailed company law. It remained liable for the monitoring of the company, even when external auditors were appointed [see above, also Gietzman and Quick, 1998, p. 85 and Beigel, 1924]. Further, while according to agency theory auditing is one of the ways of reducing agency costs, in Germany an independent external audit appears to have been expensive [see e.g. Buxbaum, 1910], unless it could be provided by a firm within the same group.

If self-regulation had been more successful, professional associations might have been a means of reducing the cost of ensuring auditor competence and independence and the audit might have provided better value for money. However, in Germany the profession failed to sufficiently convince the market or the state of their members' competence. Nevertheless, there appears to have been a perception that an audit regulated by the government would ensure the required quality and reduce agency costs.

The audit developed differently from that in the UK. Its scope in Germany was narrower and the auditors saw the supervisory board, rather than the shareholders, as their main principal. It can be argued that an external audit was not really required to the same extent as in the UK, because, as suggested above, due to different corporate governance arrangements the separation between ownership and control was limited.

Agency theory and related assumptions regarding the organizational and legal forms of audit firms are now examined in the German context, under the headings established earlier in the paper.

Reputation and Professional Associations: As outlined above, reputation and membership of professional associations can serve as the auditor's collateral bond [Watts and Zimmerman, 1986, Chapter 13]. Further, membership of a professional association signals the auditor's competence and independence [ibid.]. In the UK professional associations have a long history, as has professional self-regulation. Velayutham [1996] argues that corporatization is detrimental to professional selfregulation because this is achieved through the control of individuals, i.e. firms that take the form of partnership are more easily regulated through their individual owners. As we have 
seen, in Germany the different professional groups also began to form associations long before the profession was regulated by the state. The question arises whether these associations were founded for the same reasons, intended to serve the same purposes as their British counterparts, and whether their creation supports Watts and Zimmerman's arguments.

It appears that the motives for professional organization were perhaps more heterogeneous in Germany than in the UK. Clearly, the motivation of the BR, who founded the earliest association (the VDB), was similar to that of their UK counterparts. It could also be argued in support of Watts and Zimmerman's assumption that the BR intended to raise their members' reputation by standardizing audit quality and education requirements, thus signaling their competence. As suggested by Hintner [1926], those firms who had little to offer by way of financial bonds would have benefited from organization - essentially letting reputation and membership of an association serve as a bond. The associations formed by the smaller THGs seemed to have been driven by similar considerations. The Verband Deutscher Treuhand- und Revisionsgesellschaften, for example, did not accept bank-owned THGs as members because of concerns over independence [Haibt, 1998]. However, it appears that in the UK reputation and membership of professional associations were more important than in Germany because English law did not provide much guidance to the auditor and the audit opinion was to a larger extent based on subjective professional judgment. Thus the reputation of the auditor was crucial in adding credibility to the audited accounts [Hintner, 1926, p. 140]. Hintner seems to consider the "good name" of the auditor in the UK as synonymous with the title of chartered accountant.

In Germany, for the large audit corporations, especially those owned by banks, the motivation for forming professional associations was probably different. They did not require nonfinancial bonds to the same extent as the BR, and while they were not independent, they had less need for a reputation of independence. However, when the BR and the smaller THGs attempted to achieve regulation of the audit and the profession, the larger THGs required an organization to represent their interests. Following Velayutham's [1996] suggestion, their resultant associations would have found it more difficult to regulate their members and would have been unlike the associations formed by the British profession.

Probably to a greater extent than the British profession, in the 1920s the German associations lobbied the government for 
audit regulation. This may have been an attempt to gain market control. It may also have been due to the fact that, while the German profession looked towards the UK profession as a model [see e.g. Karoli, 1934, p. 21], its members misunderstood the role of the state (and of the Royal Charter) in the UK. Karoli's interpretation of the developments in the UK suggest that he believed there to be a considerable degree of state interference [1934, pp. 19-20]. It is possible that such perceptions of state initiatives in the UK was an additional reason why German auditors lobbied for state intervention. It is perhaps more likely that, as a result of the environmental and cultural differences discussed above, the German profession employed a different strategy to "credentialize its expertise" by relying on academic education and state regulation [Gietzmann and Quick, 1998, p. 90].

Organisational Form: Agency theory/contracting theory makes the following claims: unlimited liability provides larger collateral bonds in the form of the partners' personal assets [Watts and Zimmerman, 1986, Chapter 13]; unlimited liability signals the auditors' independence to the market [ibid.]; risk is not divisible or transferable, hence larger resources are required for monitoring and only limited capital is available for expansion and diversification [Milgrom and Roberts, 1992, p. 522]; joint and several liability provides strong incentives for mutual monitoring [ibid.]; mutual monitoring increases incentives for competence and independence [Watts and Zimmerman, 1986, Chapter 13]; and, audit firms have few assets - the most important asset being human capital [Milgrom and Roberts, 1992, pp. 522523].

In 1926 Hintner [pp. 120, 138] argued that the large accountancy firms in the UK were comparable to the German audit corporations because they, too, relied on the division of labor. They were managed by a number of owners and often employed a staff of up to 100 , and as a rule more than 10 . The only and purely external difference, according to Hintner, was that the German audit firms were legal entities, while the English firms were partnerships. This was an oversimplification. Many of the agency theory/contracting theory assumptions do not apply to German THGs, especially the large ones linked to banks or commercial groups. If formed as an AG, they would have had to meet the considerable capital requirement legally prescribed for this form. If founded by the government or banks, the raising of this capital would not have been a problem and, as argued 
above, would be available as a substantial collateral bond. The limitation of liability would have reduced the incentives for mutual monitoring. The need for monitoring would have been (in theory at least) partially met by the supervisory boards, although it is unlikely that these were involved in monitoring the audit work itself as they lacked the expertise and would have been prevented by confidentiality rules. Firms founded and owned by banks could not be considered to be independent, especially if their shares were held by audit clients. However, this also meant that they were less dependent on a free market and, therefore, did not need to signal their independence and competence in order to compete. The German legal definition of the audit client differed from that in Anglo-American countries as a result of the role of banks in corporate governance [Gietzmann and Quick, 1998, p. 82].

Finally, Fama and Jensen [1983b, p. 334] suggest that the residual claims of professional partnerships are characterized by flexible sharing rules, inalienability and limited horizons. These features distinguish them from the residual claims of other organizations and are retained when professional partnerships become corporations. ${ }^{27}$ This does not apply to German THGs during the period under investigation, since it was possible to sell ownership shares in an audit firm to non-auditor outsiders (although Hintner, [1926, p. 60] claims that this was not common).

Size: Agency theory/contracting theory suggests that larger firms can offer larger bonds, provide greater opportunities for mutual monitoring and may be better able to develop brand names [Watts and Zimmerman, 1986, Chapter 13]. This situation applied to German corporate firms. However, while in the UK, with its large professional partnerships, the residual claimants were also audit experts, this was not the case in German audit corporations. This had implications for the need for monitoring, which was to some extent carried out by the audit firms' supervisory boards. Also the suggestion that decision control systems would be similar for different types of organizations did not apply in Germany, but the crucial factor appears to have been less the size or even the legal form of the audit firm, but rather whether it was owned and controlled by auditors or by external owners. Other size-related factors were the ability of the larger audit firms to provide specialization and offer a range of

${ }^{27}$ This appears to be supported by van Lent's [1999] evidence regarding KPMG in the Netherlands. 
services, which enabled them to increase their market share. Further aspects of size have already been covered, where relevant, under the other two headings above.

\section{SUMMARY AND CONCLUSIONS}

This paper examined the development of auditing and attitudes to the legal and organizational forms of audit firms in Germany prior to the formal regulation of the audit and the audit profession in 1931. It concluded that there were parallel developments in the UK and US, drawn on by Watts and Zimmerman [1983] as evidence for certain agency theory assumptions, and that, in particular, a separation of ownership and control and similar agency problems existed. However, due to different financing and corporate governance arrangements in Germany these occurred to a lesser extent than in the UK and US. Further, it was not generally accepted until relatively late that an independent external audit would provide the best solution to these problems. When the independent external audit was considered, it was only in addition to the monitoring functions of the earlier German solution, the supervisory board, and its acceptance appears to have been strongly influenced by the British example. Thus auditing developed much later in Germany as a secondary device to facilitate the supervisory board's monitoring duties.

The paper's findings suggest that explanations offered for the partnership form of audit firms by agency theorists may be over-generalizing the role of professional organizations in familiar Anglo-American cultural contexts. These theories may also have limited explanatory value in relation to different cultures and traditions. The findings of this paper suggest that different attitudes to the organizational features of audit firms appeared only partly to be determined by legal form. Perhaps greater explanatory value is offered by the factor of size. This is supported by Fama and Jensen's [1983a, 1983b] claim that certain features of professional firms are retained even when these firms incorporate. Van Lent's [1999] more recent findings regarding KPMG in the Netherlands also suggests that the organizational/governance structure did not change significantly when the firm incorporated. However, an alternative, and possibly even more significant explanatory factor for audit firms' features is ownership, i.e. by auditors versus external non-auditors, and thus the question whether decision makers are also the residual riskbearers. The ownership of KPMG in the Netherlands did not 
change when the firm altered its legal form, and thus its governance did not change.

Further, as the audit market in Germany during the period under investigation was structured differently from that in the UK or US, it was less important to signal independence because appointments were often arranged through the banks as joint owners/capital providers of audit firms and clients. Finally, the objective of the audit differed. In Germany the emphasis was (and to some extent still is) more on compliance with law and regulations, and less (as in Anglo-American countries) on the assessment of fair presentation or true and fair view. This was linked to different ownership and corporate governance structures in German compared to Anglo-American audit clients. As a result, German auditors acted as agents to the supervisory boards rather than to the shareholders [Gietzmann and Quick, 1998, p. 83] and were intended to aid the supervisory board in discharging its accountability to shareholders. This again suggests that independence was seen to be less important.

With regard to the paper's subsidiary objective, the examination of the limitations of Watts and Zimmerman's and more general agency theory assumptions, it appears that, although Watts and Zimmerman [1983] utilize historical evidence in support of their approach, agency theory is flawed as a basis for historical theorization. The findings of the current study reinforce Gray and Calvasina's [1995, p. 35] warning against "extending modern rational expectations and assumptions to earlier periods of history". On closer examination and in the light of recent developments, much of the agency theory explanation for the legal and organizational form of audit firms is also suspect in the UK and US contexts. For example, Lee [1993, p. 111] argues that the suggestion that auditor liability is an incentive for competence and independence [see Watts and Zimmerman, 1986, pp. 316-318]: "is inconsistent with recent developments in the US and elsewhere to incorporate audit firms with limited liability - that is, the position taken by such bodies as the AICPA in the US that incorporation is permissible as a means of restricting the exposure of auditors to the considerable financial loss of litigation".

It may be concluded that agency theory is less suitable as a foundation for historical theorization than approaches which analyze historical events within their social contexts [see Mills, 1993]. In other words, agency theory, its philosophical and methodological shortcomings aside, is too narrow to form a satisfactory basis of explanation. This highlights the importance of 
analyzing developments in the history of German auditing in their particular contexts. The present paper has attempted to provide an overview of these developments. Further detailed study is required to better understand the complex history of auditing and the organizational forms of audit firms in Germany.

\section{REFERENCES}

Allgemeine Begründung zum Gesetz betreffend die Kommanditgesellschaften auf Aktien und die Aktiengesellschaften (1884), Verhandlungen des Reichstags, 5. Legislaturperiode, Session 4, Aktenstück Nr. 21: 236-350.

Beigel, R. (1924), Lehrbuch der Buchführungs- und Bilanz-Revision; fourth edition (Dresden: Verlag von Gerhard Kühtmann).

Broadbent, J., Dietrich, M. and Laughlin, R. (1996), "The Development of Principal-agent, Contracting and Accountability Relationships in the Public Sector: Conceptual and Cultural Problems," Critical Perspectives on Accounting, Vol. 7, No. 3: 259-284.

Buxbaum, R. (1910), Die Bank, Septemberheft 1910.

Christenson, C. (1983), "The Methodology of Positive Accounting," Accounting Review, Vol. 58, No. 1: 1-22.

Chua, W.F. (1986), "Radical Developments in Accounting Thought," Accounting Review, Vol. 61, No. 4: 601-632.

Fama, E.F. and Jensen, M.C. (1983a), "Separation of Ownership and Control," Journal of Law and Economics, Vol. 26, June: 301-326.

Fama, E.F. and Jensen, M.C. (1983b), "Agency Problems and Residual Claims," Journal of Law and Economics, Vol. 26, June: 327-349.

Gareis, R. (1900), Handelsgesetzbuch vom 10 Mai 1897 nebst dem Einführungsgesetze vom 10 Mai 1897 (München C.H. Beck'sche Verlagsbuchhandlung).

Gesetz betreffend die Kommanditgesellschaften aud Aktien und die Aktiengesellschaften (1870), Bundes-Gesetzblatt 25 June 1870.

Gesetz betreffend die Kommanditgesellschaften aud Aktien und die Aktiengesellschaften (1884), Reichs-Gesetzblatt 31 Juli 1884.

Gietzmann, M. and Quick, R. (1998), "Capping Auditor Liability: the German Experience," Accounting, Organizations and Society, Vol. 23, No. 1: 81-103.

Gray, O.R. and Calvasina, R.V. (1995), "The 1926 Contract for Construction of Facilities at the Pensacola Naval Station and its Implications for Historical Research using Agency Theory," Accounting Historians Journal, Vol. 22, No.1: 35-55.

Greenwood, R., Hinings, C.R. and Brown, J. (1990), "P2- form Strategic Management: Corporate Practices in Professional Partnerships," Academy of Management Journal, Vol. 33, No. 4: 725-755.

Haibt, H. (1998), Kapitalbeteiligung Berufsfremder an Wirtschaftsprüfungsgesellschaften (Bonn: Deutscher Anwaltverlag).

Handelsgesetzbuch (1897), Reichsgesetzblatt. Nr. 2388. 10 May 1897: 219-436.

Henning, F. (1990), "Die externe Unternehmensprüfung in Deutschland vom 16. Jahrhundert bis zum Jahre 1931," Vierteljahrschrift für Sozial- und Wirtschaftsgeschichte, Vol. 77, No. 1: 1-28.

Hintner, O. (1926), Das Treuhandwesen in der deutschen Volkswirtschaft; Habilitationsschrift (Muenchen/ Berlin/Leipzig : J. Schweitzer Verlag). 
Hunt, H. G. and Hogler, R. L. (1990), “Agency Theory as Ideology: A Comparative Analysis Based on Critical Legal Theory and Radical Accounting," Accounting, Organizations and Society, Vol. 15, No. 5: 437-454.

Jensen M. C. and Meckling, W. H. (1976), "Theory of the Firm: Managerial Behavior, Agency Costs and Ownership Structure," Journal of Financial Economics, Vol. 3, October: 305-360.

Karoli, R. (1934), Bilanzprüfung und Prüfungsergebnis, ihr Wesen und ihre Bedeutung für Unternehmung, Öffentlichkeit und Prüferberuf; Dissertation (Leipzig: Hugo Günther \& Co).

Klausing, F. (1933), Reform des Aktienrechts (Berlin/Wien: Industrieverlag Spaeth \& Linde).

Kocka, J. (1990), “Bürgertum' and Professions in the Nineteenth Century: Two Alternative Approaches," in Burrage, M. and Torstendahl, R. (eds), Professions in Theory and History. Rethinking the Study of the Professions (London: Sage): 62-74.

Lansburgh, A. (1908), "Revisionsgesellschaften", Die Bank.

Lee, T. (1993), Corporate Audit Theory (London: Chapman \& Hall).

Leffson (1988), Wirtschaftsprüfung; fourth edition (Wiesbaden: Gabler Verlag).

Markus, H.B. (1997), The History of the German Public Accounting Profession (New York/London: Garland).

Matthews, D., Anderson, M. and Edwards, J.R. (1998), The Priesthood of Industry. The Rise of the Professional Accountant in British Management (Oxford: Oxford University Press).

Meisel, B.S. (1992), Geschichte der Deutschen Wirtschaftsprüfer (Köln: O. Schmidt).

Milgrom, P. and Roberts, J. (1992), Economics, Organization and Management (Englewood Cliffs, NJ: Prentice Hall).

Mills, P. A. (1989), "Words and the Study of Accounting History," Accounting, Auditing and Accountability Journal, Vol. 2, No. 1: 21-35.

Mills, P. A. (1993), “Accounting History as Social Science: A Cautionary Note," Accounting, Organizations and Society, Vol. 18, No. 7/8: 801-803.

Neal, M. and Morgan, J. (2000), "The Professionalization of Everyone?. A Comparative Study of the Development of the Professions in the United Kingdom and Germany," European Sociological Review, Vol. 16, No. 1: 9-26.

Penndorf, B. (1932), "Die berufliche Organisation des Revisionswesens in Deutschland. Entwicklung des Revisionswesens in Deutschland," Die Betriebswirtschaft, Vol. 25, No. 11/12: 311-313.

Quick, R. (1990), "Die Entstehungsgeschichte der aktienrechtlichen Pflichtprüfung in Deutschland," Zeitschrift für Unternehmensgeschichte, Vol. 35: 217-236.

Raschenberger, M. (1929), Internationales Revisions- und Treuhandwesen (Wien: Hölder-Pichler- Tempsky A.G.).

Reich, N. (1979), "Auswirkungen der deutschen Aktienrechtsreform von 1884 auf die Konzentration der deutschen Wirtschaft," in Horn, N. and Kocka, J. (eds) Recht und Entwicklung der Großunternehmen im 19. und frühen 20. Jahrhundert, (Göttingen: Vandenhoeck \& Ruprecht): 255-273.

Römer, E. (1905), Die Bücherrevisoren-Praxis in Deutschland und England; first and second editions (Berlin: E. E. Römer's Verlag).

Rosendorff, R. (1906), "Treuhandgesellschaften und ihre Funktionen," Conrads Jahrbücher für Nationalökonomie und Statistik, III. Folge, 31. Band, Jena.

Schneider, D. (1995), "The History of Financial Reporting in Germany," in Walton, P. (ed.) European Financial Reporting. A History, (London: Academic Press). 
Schröer, T. (1993), "Germany in: Company Law and Accounting in Nineteenthcentury Europe," European Accounting Review, Vol. 2, No. 2: 335-345.

Schwäbische Treuhand-Aktiengesellschaft (1931), Die Revision (Stuttgart: Schwäbische Treuhand-Aktiengesellschaft).

Theermann, A. (1930), "Pflichtrevision und Banktreuhandgesellschaften," BankArchiv, Vol. 30: 42-44.

Tinker, T., Merino, B. and Neimark, M.D. (1982), "The Normative Origins of Positive Theories: Ideology and Accounting Thought," Accounting, Organizations and Society, Vol. 7, No. 2: 167-200.

van Lent, Laurence (1999), "The Economics of an Audit Firm: The Benefits of Partnership Governance," British Accounting Review, Vol. 31, No. 2: 225254.

Velayutham, S. (1996), "Corporatization and the Regulation of Accounting Services," British Accounting Review, Vol. 28, 4: 351-368.

Verlag der Königlichen Geheimen Ober-Hofdruckerei (1867), Allgemeines Deutsches Handelsgesetzbuch und Einführungs-Gesetz, vom 24 Juni 1861 (Berlin: R. v. Decker).

Vieten, H. (1995), "Auditing in Britain and Germany Compared: Professions, Knowledge and the State," European Accounting Review, Vol. 4, No. 3: 485511.

von Falkenhausen (1930), "Aufsichtsratsfrage und Pflichtrevision", Bank-Archiv, Vol. 29, No. 22: 439-443.

Voß, W. (1927), Die obligatorische Revision im Rahmen der Reform des Aktienrechts (Berlin: Carl Heymanns Verlag).

Walker, S. P. (1995), "The Genesis of Professional Organization in Scotland: A Contextual Analysis," Accounting, Organizations and Society, Vol. 20, No. 4: 285-310.

Watts, R. L. and Zimmerman, J. L. (1983), "Agency Problems, Auditing, and the Theory of the Firm: Some Evidence," Journal of Law and Economics, Vol. 26, October: 613-633.

Watts, R. L. and Zimmerman, J. L. (1986), Positive Accounting Theory (Englewood Cliffs, NJ: Prentice Hall).

Weber-Boun, A. (1904), "Die Revisoren der englischen Aktiengesellschaften," Bank-Archiv, Vol. 3: 27-30.

Willmott, H. (1986), "Organising the Profession: A Theoretical and Historical Examination of the Development of the Major Accountancy Bodies in the U.K.," Accounting, Organizations and Society, Vol. 11, No. 6: 555-580.

Working Party on Auditing (1972), Working Paper (Brussels: Commission of the European Communities).

Zysman, J. (1983), Governments, Markets and Growth: Financial Systems and the Politics of Industrial Change (Oxford: Martin Robertson). 